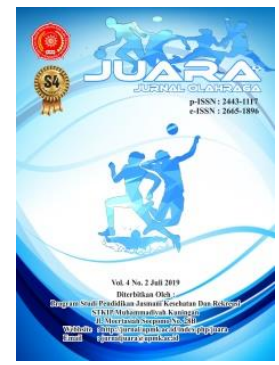

\title{
Kebugaran Jasmani Bagi Lansia Saat Pandemi Covid-19
}

\section{Physical Fitness for the Elderly During the Covid-19 Pandemic}

\author{
Syahruddin \\ Faculty of Sport Science,Universitas Negeri Makassar, Jl. A. P. Pettarani, Tidung, Kec. Rappocini, \\ Makassar City, South Sulawesi, 90222, Indonesia \\ Email: syahruddin@unm.ac.id
}

\section{Info Artikel \\ Sejarah Artikel: \\ Diterima 22 April 2020 \\ Disetujui 21 Juli 2020 \\ Dipublikasikan 29 Juli 2020 \\ Keywords: \\ Kebugaran Jasmani, Lansia, Covid-19}

\begin{abstract}
Abstrak
Pandemic Covid-19 menimpa semua negara di dunia termasuk Indonesia dan terjadi mortalitas sebagian besar adalah lansia. Upaya meningkatkan penampilan, kesejahteraan, dan kebugaran lansia melalui olahraga. Senam aerobic dengan instensitas ringan adalah mudah, murah, dan dapat meriah serta bermanfaat karena dilakukan di dalam rumah dan akan menyebabkan denyut jantung lansia masuk ke dalam training zone sehingga akan memenuhi tuntutan dan persyaratan pelatihan. Para lansia selama pandemic Covid-19 diarahkan melakukan senam dan berusaha mencapai target, yaitu berlatih tiga sampai lima kali seminggu dengan waktu latihan 30 sampai 60 menit.
\end{abstract}

\begin{abstract}
Pandemic Covid-19 afflicts all countries in the world including Indonesia and mortality is mostly elderly. Efforts to improve the appearance, wellbeing, and fitness of the elderly through sports. Aerobic aerobics with light intensity is easy, inexpensive, and can be lively and beneficial because it is done in the home and will cause the heart rate of the elderly to enter the training zone so that it will meet the demands and training requirements. The elderly during the Covid-19 pandemic are directed to do gymnastics and try to reach the target, which is practicing three to five times a week with practice time of 30 to 60 minutes.
\end{abstract}

\footnotetext{
${ }^{凶}$ Alamat korespondensi: J1. A. P. Pettarani, Tidung, Kec. Rappocini, Makassar City

E-mail : syahruddin@unm.ac.id
}

\section{PENDAHULUAN}

Lanjut usia merupakan tahap terakhir dari siklus hidup manusia, yang pastinya akan mengalami perubahan baik fisik maupun mental. Penuaan penduduk di Indonesia berkembang pesat. Saat ini penduduk lanjut usia di Indonesia telah mengalami peningkatan dari sebelumnya yaitu berjumlah sekitar 24 juta dan tahun 2020 diperkirakan akan 
meningkat sekitar 30-40 juta jiwa (Arini et al., 2020). Manusia usia lanjut adalah seseorang yang karena usianya mengalami perubahan biologis, fisik, sosial. Perubahan ini memberikan pengaruh pada seluruh aspek kehidupan, termasuk kesehatannya. (WHO, 2018) Mengklasifikasi manusia usia lanjut terdiri atas usia pertengahan (middle age) kelompok usia 45-59 tahun, usia lanjut (elderly) kelompok usia 60 -70 tahun, usia lanjut tua (old) kelompok usia antara 75 90 tahun, usia sangat tua (very old) kelompok usia diatas 90 tahun. Sedangkan (Arini et al., 2020;Barkley et al., 2020) mengklasifikasi pada lanjut usia, yaitu: 1) Pramanula (prasenilis) Seseorang yang berusia antara 45 -59 tahun, 2) Manula Seseorang yang berusia 60 tahun atau lebih, 3). Manula risiko tinggi, Seseorang yang berusia 70 tahun atau lebih / seseorang yang berusia 60 tahun atau lebih dengan masalah kesehatan, 4). Manula potensial Manula yang masih mampu melakukan pekerjaan dan/atau kegiatan yang dapat menghasilkan barang / jasa, dan 5). Manula tidak potensial. Manula yang tidak berdaya mencari nafkah, sehingga hidupnya bergantung pada bantuan orang lain. Selain itu batasan usia lansia menurut (Antczak et al., 2020) lansia digolongkan menjadi 3 kelompok yaitu : (1) kelompok lansia dini (55-64 tahun), (2) kelompok lansia (65 tahun keatas), dan (3) kelompok lansia resiko tinggi (berusia lebih dari 70 tahun).

Lanjut usia adalah seseorang yang karena usianya mengalami perubahan biologis, fisik, kejiwaan dan sosial. Semakin bertambahnya usia seseorang beberapa fungsi vital dalam tubuh ikut mengalami kemunduran fungsional (Bauman, 2004). Pendengaran mulai menurun, penglihatan kabur, dan kekuatan fisiknya pun mulai melemah. Perubahan ini akan memberikan pengaruh pada seluruh aspek kehidupan karena itu kesehatan manusia (Brauer, 2004). Lanjut Usia perlu mendapatkan perhatian khusus dengan tetap dipelihara dan ditingkatkan(Brown \& Lee, 2004). Tujunnya agar selama mungkin dapat hidup secara produktif sesuai dengan kemampuannya sehingga dapat ikut serta berperan aktif dalam pembangunan (Browning et al., 2004; Le Guennec \& Rossary, 2020). Kondisi ini diperparah oleh tidak adanya waktu, tempat, dan kesempatan bagi lansia dalam melakukan aktivitas (Barkley et al., 2020).

Saat ini, pandemi Virus COVID19 telah menyebar di 102 Negara. Awalnya virus ini penyebaran besar di mulai dari Propinsi Wuhan dataran RRC. Sampai saat ini di Indonesia tanggal 10 April 2020 telah memakan Korban 306 jiwa (Zheng et al., 2020; Zhang et al., 2020; Zhai et al., 2020). Sementara di Indonesia melalui juru bicara kementrian kesehatan dr. Achmad Yurianto, Direktur Jenderal P2P dan sebagai Ketua Gugus menyebutkan beberapa kasus pasien COVID-19 yang meninggal berada pada rentang usia sekitar 45 sampai dengan 65 tahun (Tosepu et al., 2020) Sedangkan di Italia, 85,6\% korban yang meninggal dunia akibat virus Covid-19 ini berusia diatas 70 tahun (Song J, 2020; Sohrabi et al., 2020). Hal ini terjadi akibat belum adanya vaksin yang mumpuni untuk mengobati pasien yang positif menderita Covid 19.

Untuk mengatasi pandemi sebaran virus ini, pemerintah Indonesia menganjurkan agar semua masyarakat melakukan social distance bahkan physical distance. Bagi para pekerja kantoran pekerjaan dilakukan dirumah atau wroke from home (WHF) termasuk bagi mahasiswa dan anak sekolah dalam proses pembelajaran melalui daring (online) (Arini et al., 2020; Tosepu et al., 2020).

Akibat pandemik Corona-19 itu, Propinsi DKI Jakarta sebagai episentrum 
Covid-19 mengambil kebijakan melakukan PSBB (Pembatasan Sosial Berskala Besar) bagi warga, baik yang berasal dari Jakarta itu sendiri maupun terhadap warga luar Jakarta (Tosepu et al., 2020).

Bekerja dan beraktivitas mampu dilakukan oleh setiap individu termasuk bagi lansia dalam berolahraga. Model olahraga apa yang tepat dan memberikan imunitas terhadap bagi kaum lansia serta tidak memerlukan lahan yang luas adalah olahraga senam aerobik dan diserta perasaan bahagia. Agar lansia tetap berdaya guna dapat mengadopsi akronim BAHAGIA. Artinya :

$\mathrm{B}=$ Berat badan yang berlebihan agar dihindari

$\mathrm{A}=$ Aturan makan agar tetap seimbang, cukup, dan sesuai

$\mathrm{H}=$ Hindari faktor resiko Penyakit Jantung Coroner

A = Agar tetap berguna usahakan mempunyai kegiatan/hobby

$\mathrm{G}=$ Gerak badan/olahraga yang benar dan teratur wajib terus dilaksanakan

I = Ikuti nasehat dan petunjuk dokter dan hindari situasi yang menegangkan

$\mathrm{A}=$ Awasi kesehatan dengan periksa pada dokter secara berkala.

Sejalan dengan akronim, pendapat (Listyasari, 2019) latihan yang baik untuk para lansia adalah dengan berolahraga. Jenis olahraga yang bisa dilakukan pada lansia antara lain adalah senam. Salah satu senam untuk menjaga kesehatan lansia yang paling murah dan mudah dilakukan adalah senam bugar lansia. Menurut (Listyasari, 2019) salah bentuk latihan olahraga yang baik bagi lansia adalah berjalan. Berjalan dan senam merupakan dua bentuk latihan yang bertujuan meningkatkan kardia vaskuler. Karena itu, olahraga senam bagi lansia sangat disarankan untuk memperoleh kebugaran kardiovaskuler.

Upaya yang dilakukan adalah olahraga senam aerobik dipilih karena hampir semua orang dapat melakukannya, gerakannya mudah, pelaksanaannya murah karena hampir tanpa biaya, dan bila dilakukan bersama orang banyak akan meriah. Berdasarkan pada apa yang telah dikemukakan di atas, tujuan penelitian ini untuk meningkatkan kebugaran jasmani para lansia dalam pandemic covid-19 dapat melalui olahraga senam.

\section{METODE PENELITIAN}

Artikel review diidentifikasi melalui beberapa basis data sains: Sciencedirect, ProQuest, SpryngerLink, SAGE dan Scopus yang diindeks ke Scopus, Medline atau PubMed. Kami juga memasukkan Google Cendekia sebagai sumber makalah ilmiah untuk mencari lebih banyak artikel yang mungkin tidak dipublikasikan di jurnal yang diindeks. Pencarian elektronik dilakukan untuk mengidentifikasi literatur yang relevan. Kata kunci berikut digunakan untuk mengidentifikasi artikel yang relevan: ("peringatan bergambar"; "peringatan grafis"; "peringatan kesehatan") dengan setidaknya satu dari persyaratan berikut: lansia, covid19, dan olahraga lansia. Semua artikel yang muncul dalam hasil pencarian terdaftar.

Tinjauan ini terbatas pada artikel-artikel yang melaporkan temuan-temuan penelitian asli dan diterbitkan dari Januari 2005 hingga Januari 2020. Karena keragaman metode penelitian dalam domain ini, review tidak membatasi studi untuk desain tertentu; namun, masing-masing artikel ditinjau untuk kriteria metodologis berikut: (1) tujuan dan / atau pertanyaan penelitian dijelaskan dengan jelas, (2) sampel dan / atau populasi penelitian dijelaskan, (3) metode pengumpulan data, (4) hasil didefinisikan dengan jelas dan diukur (5) analisis temuan jelas dan tepat.

Dalam melakukan ekstraksi data, pertama-tama memisahkan artikel yang tidak termasuk mewakili negara-negara Asia sebagai lokasi studi mereka. Sebanyak 121 artikel diidentifikas dan 79 artikel yang menyajikan data empiris diidentifikasi 
berdasarkan judul dan abstrak, 40 artikel diidentifikasi secara abstrak dan metode yang menghasilkan tidak termasuk 26 artikel lagi karena kurangnya informasi metodologis. 14 artikel asli yang termasuk dalam tinjauan terdiri dari 12 studi kuantitatif dan 2 studi dengan komponen kuantitatif dan kualitatif. Strategi ekstraksi dan identifikasi data menggunakan diagram alur PRISMA (Swartz, 2011).

\section{HASIL DAN PEMBAHASAN}

\section{Manfaat Latihan Senam Bagi Lansia}

Menurut (Listyasari, 2019) senam aerobik merupakan olahraga banyak diminati dan memiliki manfaat. Hal ini sejalan dengan hasil pelatihan setelah 20 minggu, Kapasitas Aerobik Maksimal meningkat 28\%, dari 2,3 $1 /$ men menjadi 2,92 1/men. Denyut jantung pelatihannya menurun sampai 17 kali semenit, sedang denyut jantung pemulihannya menurun 16 sampai 26 kali semenit. Tekanan diastole istirahat juga menurun dair 77,7 menjadi 74,9 mmHg. Disamping itu berat badan dan prosentase lemak tubuhnya juga menurun (Brauer, 2004).

Aktivitas aerobik akan menyebabkan terjadinya penurunan berat badan karena turunnya persentase lemak tubuh (Brown \& Lee, 2004). Metode latihan aerobik atau komposisi tubuh menurut (Browning et al., 2004) adalah perbandingan berat badan yang terdiri atas lemak dengan berat badan tanpa lemak. Memiliki ciri-ciri latihan dengan kontinyu, gerak yang dinamis, melibatkan otot-otot besar dan penurunan berat badan yang aman 0,5-1,0 kg/minggu sedangkan jumlah kalori yang dibakar setiap kali latihan kurang lebih 500-1000 kalori.

Menurut (Bass et al., 2004) latihan aerobik memberikan pengaruh antara lain menurunkan kerawanan terhadap penyakit jantung, menurunkan tekanan darah bagi penderita hipertensi, menurunkan kadar lemak tubuh, menurunan depresi dan kecemasan, dapat menanggulangi penyakit mental, serta mengurangi resiko penyakit tulang. Salah satu bentuk senam aerobik adalah senam lansia. (Chang et al., 2020) mengemukakan senam lansia dapat mengeliminasi berbagai resiko penyakit seperti peningkatan tekanan darah, diabetes mellitus, penyakit arteri koroner dan kecelakaan.

Kapasitas aerobik maksimal merupakan faktor penting, bahkan menentukan bagi kegiatan-kegiatan yang berlangsung lama dan membutuhkan ketahanan seperti kerja di pabrik, di pertambangan, atau usaha untuk berprestasi di cabang olah raga yang memerlukan dayatahan kardiovaskuler seperti senam. Kapasitas aerobik maksimal yang besar adalah paduan antara faktor heredity dan faktor latihan. Latihan yang benar dan teratur, terprogram serta terarah dapat meningkatkan besarnya kapasitas aerobik maksimal.

Latihan yang sifatnya aerobik mestinya terus dilakukan, terutama menjelang usia 40 tahun karena saat itu munculnya kemunduran organ-organ tubuh dengan fungsinya. Kemunduran ini pasti terjadi sejalan dengan bertambahnya usia, tidak dapat dicegah, hanya dapat diperlambat laju kemundurannya dengan terus melakukan pelatihan secara teratur dan terprogram. Latihan yang benar, teratur dan menerus bukannya mencegah proses menua, tetapi sekedar menghambat laju proses menua. Mereka yang terus berlatih dengan benar dan teratur akan nampak lebih muda dan lebih bergairah hidupnya dibanding dengan yang tidak berlatih, meskipun kedua kelompok tetap akan mengalami kemunduran-kemunduran dengan bertambahnya umur (Carlson \& Naughton, 2004).

\section{Dosis Latihan Senam Lansia}

Menurut (Barnett et al., 2013) dalam pelaksanaan senam aerobik harus berpedoman kepada dosis latihan yang disesuaikan dengan tujuan latihan. Dosis latihan selalu terkait dengan intensitas, repetisi, frekuensi, dan durasi latihan. Intensitas latihan diartikan sebagai besarnya beban yang harus dilakukan 
selama latihan dengan indikator peningkatan denyut jantung tiap menitnya atau disebut heart rate latihan. Untuk meningkatkan daya tahan aerobik cukup melakukan latihan selama 30-60 menit secara kontinyu. Pendapat lain mengatakan bahwa latihan aerobik yang dilakukan selama 8-12 minggu secara terus menerus telah memberi efek yang cukup berarti bagi perubahan faal tubuh. Senam aerobik sebagai salah satu bentuk senam yang kompleks, gerakan yang dilakukan memerlukan koordinasi yang cukup dari bagian-bagian tubuh, baik dari kepala sampai kaki. Senam aerobik mudah dilakukan, dapat diikuti oleh siapa saja, remaja, dewasa, yang tua baik laki-laki maupun perempuan.

Senam aerobik 3 kali per minggu dengan durasi 60 menit selama 12 minggu dapat meningkatkan fleksibilitas serta dan meningkatkan daya tahan jantung paru (Čuljak et al., 2014). Disarankan bagi individu dewasa muda untuk meningkatkan aktivitas fisik antara lain dengan melakukan senam aerobik minimal 3 kali per minggu secara teratur untuk meningkatkan fleksibilitas dan daya tahan jantung paru.

Penelitian terbaru menyebutkan bahwa latihan fisik yang bersifat aerobik pada lansia dapat mempengaruhi fungsi kognitif menjadi lebih baik dikemudian hari. Menurut (Listyasari, 2019) latihan aerobik dengan intesitas ringan dan sedang dapat meningkatkan fungsi kognitif pada lansia. Latihan aerobik dapat memperbaiki suasana hati bagi lansia (Ryan, 1982).

Latihan aerobik untuk merawat kesehatan lansia sebaiknya dilakukan pada pagi hari, dan tidak melebihi denyut jantung maksimal yaitu antara $60-70 \%$ dari denyut jantung maksimal. Latihan aerobik yang disarankan yaitu, berjalan, renang, bersepeda, yoga, senam lansia, dengan frekuensi 3 kali seminggu, waktu 20-30 menit menyesuaikan kemampuan lansia.

Latihan yang dilakukan harus memiliki sasaran yang jelas dan itu dapat diraih dengan menjalankan konsep FITT (Frequency, Intensity,Time and Type). Dosis konsep FITT antara lain: 1) Frekuensi. Banyaknya unit latihan persatuan waktu, untuk mencapai capaian kebugaran berupa komposisi tubuh ideal dalam latihan memerlukan latihan 3-5 kali per minggu dimana sebaiknya latihan dilakukan berselang karena hari yang lain dipergunakan untuk recovery atau pemulihan. 2) Intensitas. Besarnya intensitas bergantung pada jenis dan tujuan latihan, latihan aerobik menggunakan patokan kenaikan detak jantung (Training Heart Rate $=$ THR). Untuk tujuan pembakaran lemak $65 \%-75 \%$ detak jantung maksimal dengan penghitungan detak jantung maksimal yaitu: DJM = 220-Umur. 3) Time (waktu). Waktu atau durasi yang diperlukan setiap kali berlatih untuk meningkatkan kebugaran dan penurunan berat badan diperlukan waktu berlatih 20-60 menit dalam satu sesi latihan, dan 4). Type, atau jenis latihan. Jenis latihan senam aerobik perlu memperhatikan dasar gerak latihan kebugaran.

Intensitas latihan bagi Usia 55 tahun berlatih dalam denyut nadi 115-140/menit, usia 56 tahun berlatih dalam denyut nadi 115139/menit, usia 57 tahun berlatih dalam denyut nadi 114-138/menit, 58 tahun berlatih dalam denyut nadi 113-138/menit, Usia 59 tahun berlatih dalam denyut nadi 113-137/menit, Usia 60 tahun berlatih dalam denyut nadi 112136/menit. Sedangkan (Aarsland et al., 2020) mengemukakan bahwa latihan bagi usia 50 tahun berlatih dalam denyut nadi 102$127 /$ menit, usia 55 tahun berlatih dalam denyut nadi 99-123/menit, sedangkan 60 tahun berlatih dalam denyut nadi 96-120/menit juga memiliki efek yang signifikan bagi pengembangan kebugaran lansia.

Pada latihan aerobik intensitas ringan dan sedang, sumber energi utama yang digunakan berasal dari lemak. Latihan dengan intensitas ringan dan sedang tidak menstimulasi proses glikolisis, namun yang terjadi adalah peningkatan oksidasi asam lemak sebagai sumber energi. Otot 
menggunakan energi dari asam lemak bebas dan trigliserida. Semakin lama kontraksi otot semakin meningkat lipolisis. Selain intensitas latihan, durasi latihan juga perlu diperhatikan untuk menurunkan persentase lemak tubuh. Sedangkan untuk menurunkan lemak tubuh diperlukan waktu lebih dari 30 menit setiap kali latihan karena dalam waktu tersebut mulai terjadi lipolisis di jaringan adiposa. Proses lipolisis juga dipengaruhi oleh adrenalin yang akan merangsang lipase. Kadar adrenalin akan mencapai puncak pada menit ke 60 dari rangkaian latihan fisik yang dilakukan, sehingga latihan yang dilakukan selama satu jam atau lebih akan memiliki efek yang cukup baik bagi penurunan persentase lemak tubuh.

\section{KESIMPULAN}

Dalam situasi wabah virus Covid-19, sebaiknya setiap individu mampu menjaga kebugarannnya termasuk lansia melalui senam yang sifatnya aerobik dengan harapan lansia dapat menunaikan tugas hariannya dengan baik dan tanpa mengalami kelelahan yang berlebihan. Program latihan yang efektif bagi lansia dapat dilakukan melalui warm up, latihan inti sifatnya aerobik dapat ditambah latihan musculoskletel (caleshenics, weight training), serta cowlingdown. Selama latihan, lansia tetap perlu mempertimbangkan dosis FITT (frekuensi, intensitas, time, dan tempo).

Model senam yang tepat bagi lansia antara lain mengikuti irama dengan tahapan berjalan ditempat, naik turun bangku yang disesuikan dengan ketinggian (minimal $15 \mathrm{~cm}$ ) dengan sasaran mengarah pada penguatan sistem kardio-respirasi-vaskuler sehingga sistem imun tubuh meningkat dan bahagia.

\section{UCAPAN TERIMA KASIH}

Terimakasih kepada subjek penelitian yang telah bersedia mengikuti proses penelitian ini dengan baik, dan terimakasih juga kepada tim pembantu sehingga penelitian ini berjalan lancar.

\section{DAFTAR PUSTAKA}

Aarsland, V., Borda, M. G., Aarsland, D., Garcia-Cifuentes, E., Anderssen, S. A., Tovar-Rios, D. A., ... Perez-Zepeda, M. U. (2020). Association between physical activity and cognition in Mexican and Korean older adults. Archives of Gerontology and Geriatrics, 104047. https://doi.org/10.1016/J.ARCHGER.202 0.104047

Antczak, D., Lonsdale, C., Lee, J., Hilland, T., Duncan, M. J., del Pozo Cruz, B., ... Sanders, T. (2020). Physical activity and sleep are inconsistently related in healthy children: A systematic review and metaanalysis. Sleep Medicine Reviews, 51, 101278.

https://doi.org/10.1016/J.SMRV.2020.10 1278

Arini, Hadju, V., Usman, A. N., \& Arundhana, A. I. (2020). Physical activity in affecting hemoglobin changes $(\mathrm{Hb})$ in adolescent females received Moringa oleifera (MO) supplementation in Jeneponto. Enfermería Clínica, 30, 6972.

https://doi.org/10.1016/J.ENFCLI.2019.0 7.033

Barkley, J. E., Lepp, A., Santo, A., Glickman, E., \& Dowdell, B. (2020). The relationship between fitness app use and physical activity behavior is mediated by exercise identity. Computers in Human Behavior, 108, 106313. https://doi.org/10.1016/J.CHB.2020.1063 13

Barnett, L. M., Hardy, L. L., Lubans, D. R., Cliff, D. P., Okely, A. D., Hills, A. P., \& Morgan, P. J. (2013). Australian children lack the basic movement skills to be active and healthy. Health Promotion Journal of Australia, 24(2), 82-84. https://doi.org/10.1071/HE12920 
Bass, S. L., Nowson, C., \& Daly, R. M. (2004). Reducing the risk of osteoporosis: the role of exercise and diet. Optimizing Exercise and Physical Activity in Older People, 99-124. https://doi.org/10.1016/B978-0-75065479-1.50009-1

Bauman, A. (2004). Health benefits of physical activity for older adults epidemiological approaches to the evidence. In Optimizing Exercise and Physical Activity in Older People (pp. 125).

Elsevier. https://doi.org/10.1016/B978-0-75065479-1.50004-2

Brauer, S. G. (2004). Effects of dual task interference on postural control, movement and physical activity in healthy older people and those with movement disorders. Optimizing Exercise and Physical Activity in Older People, 267-287. https://doi.org/10.1016/B978-0-75065479-1.50016-9

Brown, W. J., \& Lee, C. (2004). Grandmothers on the move: benefits, barriers and best practice interventions for physical activity in older women. Optimizing Exercise and Physical Activity in Older People, 26-37. https://doi.org/10.1016/B978-0-75065479-1.50005-4

Browning, C., Menzies, D., \& Thomas, S. (2004). Assisting health professionals to promote physical activity and exercise in older people. Optimizing Exercise and Physical Activity in Older People, 38-62. https://doi.org/10.1016/B978-0-75065479-1.50006-6

Carlson, J., \& Naughton, G. (2004). Physical activity and health in an ageing workforce. Optimizing Exercise and Physical Activity in Older People, 63-75. https://doi.org/10.1016/B978-0-75065479-1.50007-8

Chang, A. H., Song, J., Lee, J., Chang, R. W., Semanik, P. A., \& Dunlop, D. D. (2020).
Proportion and associated factors of meeting the 2018 Physical Activity Guidelines for Americans in adults with or at risk for knee osteoarthritis. Osteoarthritis and Cartilage. https://doi.org/10.1016/J.JOCA.2020.03. 007

Čuljak, Z., Delaš Kalinski, S., Kezić, A., \& Miletić, D. (2014). Influence of fundamental movement skills on basic gymnastics skills acquisition. Science of Gymnastics Journal, 6(2), 73-82.

Le Guennec, D., \& Rossary, A. (2020). The interrelationship between physical activity and metabolic regulation of breast cancer progression in obesity via cytokine control. Cytokine \& Growth Factor Reviews, 52, 76-87. https://doi.org/10.1016/J.CYTOGFR.202 0.02 .001

Listyasari, E. (2019). Perbandingan Latihan Senam Jumsihat 1 Dengan Senam Jumsihat 2 Terhadap Kebugaran Jasmani. JUARA : Jurnal Olahraga, 4(1), 27. https://doi.org/10.33222/juara.v4i1.386

Organization, W. H. (2018). Physical activity. Retrieved April 14, 2020, from https://www.who.int/news-room/factsheets/detail/physical-activity

Ryan, R. . (1982). Control and information in the intrapersonal sphere: An extrinsic of cognitive evaluation theory. Journal of Personality and Social Psychology, 43, 450-461.

Sohrabi, C., Alsafi, Z., O’Neill, N., Khan, M., Kerwan, A., Al-Jabir, A., ... Agha, R. (2020). World Health Organization declares global emergency: A review of the 2019 novel coronavirus (COVID-19). International Journal of Surgery, 76, 7176. https://doi.org/10.1016/j.ijsu.2020.02.034

Song J, et al. Z. N. Z. D. W. W. L. X. Y. B. (2020). A Novel Coronavirus from 
Patients with Pneumonia in China, 2019. New England Journal of Medicine, 382(8), 727-733. https://doi.org/10.1056/NEJMoa2001017

Swartz, M. (2011). The PRISMA statement: a guideline for systematic reviews and meta-analyses. J Pediatr Health Care, 25(1), 1-2.

Tosepu, R., Gunawan, J., Effendy, D. S., Ahmad, L. O. A. I., Lestari, H., Bahar, H., \& Asfian, P. (2020). Correlation between weather and Covid-19 pandemic in Jakarta, Indonesia. Science of The Total Environment, 138436. https://doi.org/10.1016/J.SCITOTENV.2 020.138436

Zhai, X., Ye, M., Wang, C., Gu, Q., Huang, T., Wang, K., ... Fan, X. (2020). Associations among physical activity and smartphone use with perceived stress and sleep quality of Chinese college students.
Mental Health and Physical Activity, 18, 100323.

https://doi.org/10.1016/J.MHPA.2020.10 0323

Zhang, B., Liu, Y., Zhao, M., Meng, X., Deng, Y., Zheng, X., ... Han, Y. (2020). Differential effects of acute physical activity on executive function in preschoolers with high and low habitual physical activity levels. Mental Health and Physical Activity, 100326. https://doi.org/10.1016/J.MHPA.2020.10 0326

Zheng, X., Chen, J., Guo, Y., Xiong, Q., Hu, Y., Shi, S., ... Yu, Q. (2020). The Buffer Effect of Physical Activity: Why Does Parental Marital Satisfaction Affect Adolescents' Problematic Internet Use. Addictive Behaviors Reports, 100271. https://doi.org/10.1016/J.ABREP.2020.1 00271 